\title{
Morphological and Biochemical Changes in Ginseng Seedling Roots Affected with Stripe Symptoms
}

\author{
Zamir K. Punja ${ }^{*}$, Mahfuzur Rahman² \\ ${ }^{1}$ Department of Biological Sciences, Simon Fraser University, Burnaby, Canada \\ ${ }^{2}$ WVU Extension Service, West Virginia University, Morgantown, USA \\ Email: ${ }^{*}$ punja@sfu.ca
}

Received 24 June 2015; accepted 12 July 2015; published 19 October 2015

Copyright (C) 2015 by authors and Scientific Research Publishing Inc.

This work is licensed under the Creative Commons Attribution International License (CC BY). http://creativecommons.org/licenses/by/4.0/

(c) (i) Open Access

\begin{abstract}
A unique symptom of longitudinal red stripes on the surface of one-year-old ginseng roots was studied to determine the morphological and biochemical changes taking place. Light and scanning electron microscopy, measurements of phenolic and mineral element content, and enzyme activity, were compared between healthy and stripe-affected root tissues. Light microscopy revealed that the root epidermis had ruptured and fissures extended for 3 - 4 cell layers into the cortex. Phenolic compounds accumulated in the epidermal cells which stained with Toluidine blue 0 . Total phenolic content was higher in tissues from striped roots compared to healthy roots and HPLC profiles showed increases in a number of specific phenolic compounds. Analysis of epidermal tissues by SEM-EDX for mineral element content showed a marked increase in levels of iron, silicon and aluminum and a decline in potassium in striped root tissues. The activity of the enzymes phenylalanine ammonia lyase and peroxidase were also found to be higher in striped root tissues. Striping of ginseng roots is a physiological condition caused by a rupture of the epidermis due to rapid growth of underlying cells, which results in phenolic accumulation and sequestration of several minerals. Further oxidation causes a visible red striping on the root surface.
\end{abstract}

\section{Keywords}

Cell Disruption, Iron Sequestration, Panax quinquefolius, Phenolics, Root Epidermis

\section{Introduction}

Ginseng (Panax species, Family Araliaceae) is a medicinal plant which is cultivated in various parts of North

${ }^{*}$ Corresponding author.

How to cite this paper: Punja, Z.K. and Rahman, M. (2015) Morphological and Biochemical Changes in Ginseng Seedling Roots Affected with Stripe Symptoms. American Journal of Plant Sciences, 6, 2550-2560.

http://dx.doi.org/10.4236/ajps.2015.616257 
America, Asia, Australia and other regions of the world [1]. The root (rhizome) has been used in traditional Chinese medicine and is gaining increasing attention for use as a medicinal herb worldwide. In Canada, American ginseng (Panax quinquefolius L.) is cultivated in regions of British Columbia and Ontario and the root is harvested, dried, trimmed, and shipped for export to Asia. Ginseng root quality is determined by shape, size and overall appearance. Blemish-free roots are highly valued and any surface discolorations can significantly reduce market value. Ginseng plants are initiated from stratified seed planted in the fall, and a thick layer of straw mulch is placed on the soil surface. After seedlings emerge in the spring (first-year), the plants are grown for an additional 3 - 4 growing seasons to reach a marketable size [1]. During the four-year growth cycle, ginseng plants can be affected by a number of fungal diseases and abiotic stress factors which can affect root quality [2] [3]. A considerable amount of genetic diversity also exists among ginseng plants in cultivated fields that can lead to variation in morphological traits [4]. Previous studies have shown that physiological (abiotic) and biotic factors can cause root discoloration of the ginseng root surface and distortion of root growth. The abiotic factors include anaerobic soil conditions during root growth [5], ethylene production under stress conditions [6], and soil conditions in which iron accumulates to toxic levels in the tissues [5] [7]. In addition, reddish-brown to orange-brown discolored regions near the crown of the root were shown to be due to infection by fungi that included Fusarium spp. [8], Cylindrocarpon destructans [9], and Rhexocercosporidium sp. [10]. These fungi caused root rot as well as extensive distortion and discoloration of the root.

During annual surveys conducted on ginseng farms in British Columbia to assess the occurrence and incidence of seedling and root diseases, a unique discoloration on the root surface that consisted of longitudinal stripes (striped root) near the crown of the root was observed in different years of sampling (2008-2012). The symptoms did not resemble any of the previously described diseases or disorders associated with ginseng roots [2] [3] [6]-[10]. The objective of this research was to determine the morphological and biochemical changes occurring in the affected roots in an effort to establish the causes of the striping symptom.

\section{Materials and Methods}

\subsection{Root Samples}

Commercial ginseng fields from which root samples were obtained were located in Kamloops, BC and were sampled during the months of June to September. Roots showing longitudinal stripes (see Figure 1) were selected primarily from one-year-old plantings (in the year following seeding the previous fall season) where the symptoms predominated on seedling roots. Most of the roots were collected in the later part of the growing season (August-September) in two consecutive years. Harvested roots (approx. 100 in total) were placed inside plastic bags and transported to the laboratory in a cooler and stored at $4{ }^{\circ} \mathrm{C}$ and used for the experiments below. Field sites where striped roots were observed were marked and re-visited the following year to observe progression of symptom development.

\subsection{Light Microscopy}

Segments of root tissues approx. $2 \mathrm{~mm}^{2}$ with visible stripe symptoms (Figure 1) were cut from affected roots and placed in a fixative for $72 \mathrm{hr}$ (formalin: acetic acid: alcohol, 1:1:1) and then dehydrated in an ethanol series (70\% to $100 \%, 2 \mathrm{hr}$ in each). The tissue pieces were pre-infiltrated in a 100\% ethanol: 2-hydroxyethylmethacrylate mixture (1:1, v/v) (Technovit 7100, Marivac Ltd., Halifax, NS). Samples were then infiltrated in Technovit 7100 (100 ml plus $1 \mathrm{~g}$ hardner) for $24 \mathrm{hr}$ at $4^{\circ} \mathrm{C}$ and then embedded in Technovit. Cross-sections of the tissue were made using an LKB pyramitome (Diversified Equipment Corp., Lorton, VA) to a thickness of 4 - 8 $\mu \mathrm{m}$. The sections were stained with Toluidine Blue $0(0.05 \%)$ for $30 \mathrm{sec}$ and rinsed in water. The sections were placed on microscope slides, dried at $50^{\circ} \mathrm{C}$ for $10 \mathrm{~min}$, and sealed under a coverslip using Permount (Fisher Scientific Canada, Ottawa, ON). The sections were examined at magnifications of 100 - $400 \mathrm{X}$ under a Zeiss light microscope. Control tissues taken from roots without any striping were included for comparison. A minimum of 5 sections of each root sample was examined.

\subsection{Scanning Electron Microscopy}

Samples of small root segments $\left(1 \mathrm{~mm}^{2}\right)$ containing striped tissue were prepared for scanning electron microscopy (SEM) and energy-dispersive spectroscopy analysis (EDX) to observe morphological changes on the root 


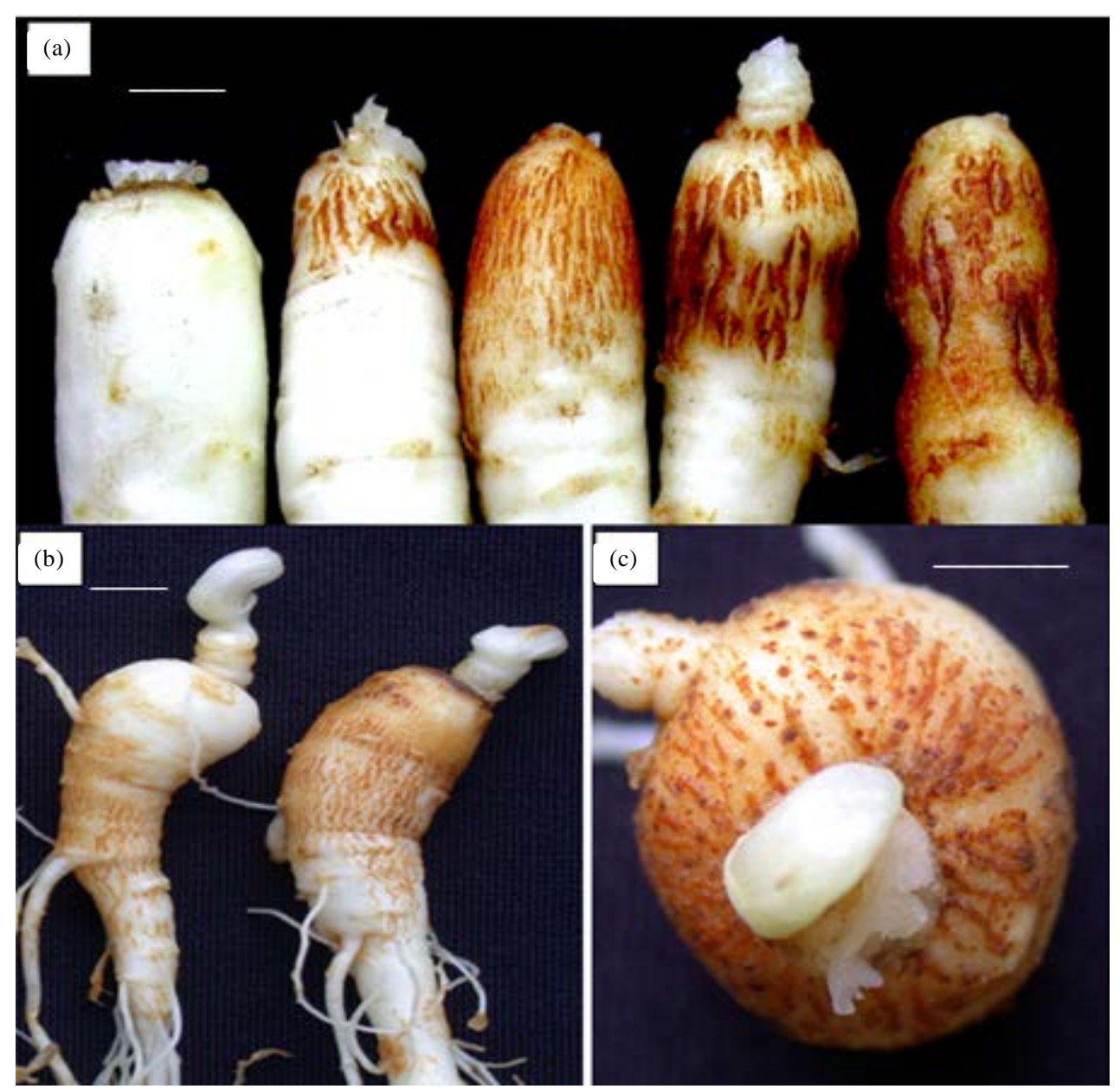

Figure 1. Symptoms of striping on ginseng seedling roots. (a) Healthy root (extreme left) compared to various stages of striping that develop on the top portion of the root. The roots on the extreme right show splitting of the epidermis and intense red colour development; (b) stripe symptoms extending down to almost two-thirds of the root; (c) top view of a seedling root with stripe symptoms. The white structure at the top of the root is the vegetative bud for the following year's growth. Scale bar = $1 \mathrm{~cm}$.

surface and identify metal compounds in epidermal cells, respectively. Healthy root tissues were included as a control. For SEM, the tissues samples were fixed in $0.1 \mathrm{M}$ cacodylate buffer containing $2 \%$ glutaraldehyde, $4 \%$ formaldehyde and $4 \%$ sucrose using standard microwave processing [11]. Samples were post-fixed in $2 \%(\mathrm{w} / \mathrm{v})$ tannic acid, followed by fixation in $1 \%$ osmium tetroxide in the above buffer for $1 \mathrm{~h}$ at room temperature, and $2 \%$ aqueous uranyl acetate for $1 \mathrm{~h}$ at room temperature in the dark. The samples were then dehydrated in a graded ethanol series and critical point-dried using $\mathrm{CO}_{2}$. Samples were mounted on stubs using colloidal silver, sputter-coated with gold-palladium in a Nanotech SEMPrep II Sputter Coater and examined in a scanning electron microscope (Hitachi S4700). For EDX, the tissue samples were immediately frozen in liquid nitrogen and freeze-dried for $48 \mathrm{hr}$, after which the samples were adhered to a metallic stub and carbon-coated to make the sample conductive. The samples were analyzed in a Hitachi S-3000 N, EDX QuartzX one (Tokyo, Japan).

\subsection{Mineral Element Determination}

The roots selected for this assay were first gently washed in deionized water several times and blotted dry. The striped tissues were gently scraped from the root surface using a sharp scalpel and bulked to obtain a composite sample. Healthy root tissues were included as a control. Air-dried $(0.2 \mathrm{~g})$ tissue was digested with $40 \%(\mathrm{v} / \mathrm{v})$ hydrofluoric acid mixed with nitric acid and made up to $100 \mathrm{ml}$ with $1 \%$ nitric acid. Aliquots of this solution 
were mixed with an internal standard and analyzed by Inductively Coupled Plasma Atomic Emission Spectrometry (ICP-AES) as described in [12]. The results were compared to a calibration curve constructed using multi-element standards and expressed in ppm. Two replicate samples were included for analysis and the procedure was repeated once using a different set of roots.

\subsection{Phenolic Compounds}

Total phenolic compounds present in striped and healthy root tissues was determined using the Folin-Ciocaleau method [13]. Using a sharp scalpel, the striped areas were gently scraped off the surface of multiple roots and bulked to provide $2 \mathrm{~g}$ (fresh weight) which was then frozen in liquid nitrogen and ground using a mortar and pestle. The tissues were mixed with $80 \%$ methanol containing $8 \%$ formic acid, stirred at $37^{\circ} \mathrm{C}$ in a water bath for $30 \mathrm{~min}$, and centrifuged at $8000 \times \mathrm{g}$ for $10 \mathrm{~min}$. One $\mathrm{ml}$ of the supernatant was added to $5 \mathrm{ml}$ of diluted (1:10, $\mathrm{v} / \mathrm{v}) \mathrm{F}-\mathrm{C}$ reagent and mixed for 30 sec. After $5 \mathrm{~min}, 4 \mathrm{ml}$ of $7.5 \% \mathrm{Na}_{2} \mathrm{CO}_{3}$ solution was added and the mixture was incubated for $2 \mathrm{hr}$ in the dark. Absorbance was measured at $740 \mathrm{~nm}$ in a Thermo Spectronic Helios UV visible spectrophotometer (Cambridge, UK) by using the reagent mix as a reference. The mean absorbance was compared to a calibration graph prepared using a range of concentrations $\left(10,25,50\right.$ and $\left.100 \mu \mathrm{g} \cdot \mathrm{ml}^{-1}\right)$ of gallic acid and the phenolic concentration was expressed as $\mu \mathrm{g} \cdot \mathrm{g}^{-1}$ gallic acid equivalents (GAE). Two replicate samples were included for analysis and the procedure was repeated once using a different set of roots.

To determine specific phenolic compounds, the above supernatant extract was evaporated to dryness using a rotary evaporator. The residue was dissolved in $5 \mathrm{ml}$ solvent (methanol, formic acid and water) and centrifuged at $12,000 \times \mathrm{g}$ for $10 \mathrm{~min}$ and filtered through a $0.2 \mu \mathrm{m}$ hydrophilic Durapore membrane filter (Millipore Corp., Bedford, MA). Fifty microliters of the extract, which constituted the mobile phase for HPLC, was injected through through an Atlantis ${ }^{\mathrm{TM}}$ dC18 column in an LC-module 1 Waters HPLC machine (Mildford, MS) at a flow rate $1.2 \mathrm{ml} / \mathrm{min}^{-1}$ and the absorbance was recorded at $280 \mathrm{~nm}$ over a 24 min retention time.

\subsection{Enzyme Assays}

Striped tissues were gently scraped from the surface of multiple roots and bulked to provide $2 \mathrm{~g}$ (fresh weight), frozen immediately in liquid $\mathrm{N}_{2}$, and homogenized with $20 \mathrm{ml}$ of extraction buffer on ice. The buffer was prepared with $80 \mathrm{ml}$ Tris-HCl (0.1 M, pH 7.8), containing $15 \mathrm{ml}$ of $10 \mathrm{mM} \beta$-mercaptoethanol, $5 \mathrm{ml} 0.5 \%$ ascorbate and three drops of glycerol. The homogenate was centrifuged at $37,000 \times \mathrm{g}$ for $10 \mathrm{~min}$ at $4^{\circ} \mathrm{C}$. The supernatant was kept on ice until the assay for enzymes was done. Three replicate samples were included in each assay.

Phenylalanine ammonia lyase (PAL). The assay mixture contained $900 \mu 1$ of $10 \mathrm{mM}$ L-phenylalanine in Tris- $\mathrm{HCl}(0.1 \mathrm{M}, \mathrm{pH} 8.8)$, and $100 \mu \mathrm{l}$ extract. The mixture was placed in a water bath at $37^{\circ} \mathrm{C}$ for $60 \mathrm{~min}$. Enzyme activity was determined using a spectrophotometer (Thermo Spectronic Helios UV visible) by the increase in absorbance at $290 \mathrm{~nm}$ over a $60 \mathrm{~min}$ interval. The change in absorbance was found to be proportional to the amount of enzyme, which produces an increase in absorbance at $290 \mathrm{~nm}$ of 1.0 per hour with a $1 \mathrm{~cm}$ light path. Specific enzyme activity was expressed as units per milligram protein of the enzyme extract. Protein concentration was measured according to Bradford [14] using bovine serum albumin (BSA) as a standard.

Peroxidase (POD). The tissue extracts were diluted 10-fold with the homogenization buffer. Pyrogallol solution $(0.05 \mathrm{M})$ was prepared in $5 \mathrm{mM} \mathrm{Na} 2\left(\mathrm{PO}_{4}\right)_{3}$ buffer $(\mathrm{pH} \mathrm{6.0)}$. One hundred microliters of the diluted extracts was mixed with $800 \mu \mathrm{l}$ pyrogallol. The reaction was started by adding $100 \mu \mathrm{l}$ of $0.6 \mathrm{M} \mathrm{H}_{2} \mathrm{O}_{2}$ to the mixture, and the rate of increase in absorbance at $470 \mathrm{~nm}$ was measured at $20 \mathrm{sec}$ intervals for a minute. Specific enzyme activity was expressed as units per milligram protein of the enzyme extract. One unit is defined as the amount that will form $1.0 \mathrm{mg}$ purpurogallin (PPG) from pyrogallol in $20 \mathrm{sec}$ at $\mathrm{pH} 6.0$ at $20^{\circ} \mathrm{C}$ by increasing the absorbance by 1.0 .

\section{Results}

\subsection{Symptoms and Light Microscopic Observations of Striped Roots}

Ginseng roots with stripe symptoms were distinctly different from healthy roots that showed no external discoloration (Figure 1(a)). Striped roots had varying degrees of reddish-orange longitudinal stripes that varied in length from $2 \mathrm{~cm}$ to up to $8 \mathrm{~cm}$ and extended down from the upper crown to more than halfway down the length 
of the root (Figure 1(b)). The stripes consisted of ridges of tissues comprised of reddish-brown material (Figure 1(c)). Light microscopic examination of the tissues showed that the cell layers stained a bluish-green with Toluidine blue 0 (Figure 2(a)), indicating the presence of phenolic compounds. The underlying cortical cells remained unstained. The ridges appeared to have formed as a result of epidermal fissures that extended down into the cortical cells, causing them to push outwards (Figure 2(b)). The fissures could be seen forming over the entire root surface, leading to multiple ridges forming on the root (Figure 3(a)). At subsequent later stages of development, the epidermal cell layers that were stained with Toluidine blue and several cortical cell layers were sloughed off by the formation of an abscission zone (Figure 3(b)). These cell layers were not seen in control roots (Figure 3(c)).

\subsection{Scanning Electron Microscopy}

Images of the surface of striped root tissues examined under a SEM confirmed that the epidermis had ruptured and cracks (fissures) were formed (Figure 4(a)), creating ridges of tissue comprised of the epidermis on either side and exposing the underlying cortical cells (Figure 4(b)). These ridges of darkly-pigmented tissues could also be seen as longitudinal lines (stripes) that made their way down the root (Figure 4(c)). Examination of the epidermal tissues using SEM-EDX revealed that there was a significant increase in the levels of silicon, aluminum and iron as seen in the spectrum analysis when compared with healthy epidermal tissues, in which only potassium was significantly higher (Figure 5). When the compositional levels of all elements were expressed as

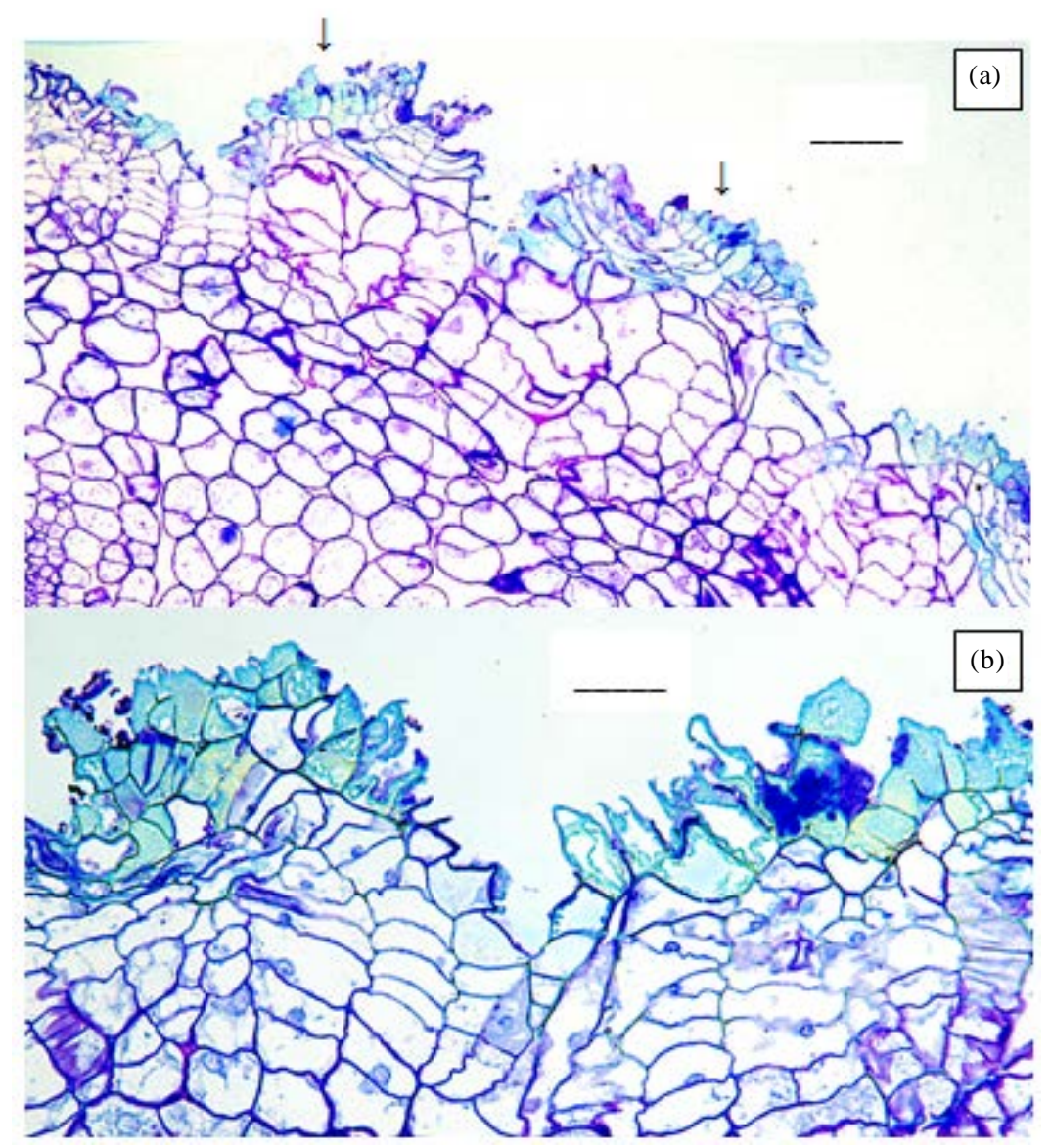

Figure 2. Light microscopic images of thin sections made through roots with stripe symptoms. (a) The epidermal cells which are stained blue with Toluidine blue 0 (arrows) form the striped areas that accumulate phenolic compounds. Note the development of fissures that develop in between the ridges; (b) close-up of bluestained epidermal cells that form a ridge of cells on either side of a fissure. Scale bar $=25 \mu \mathrm{m}$. 

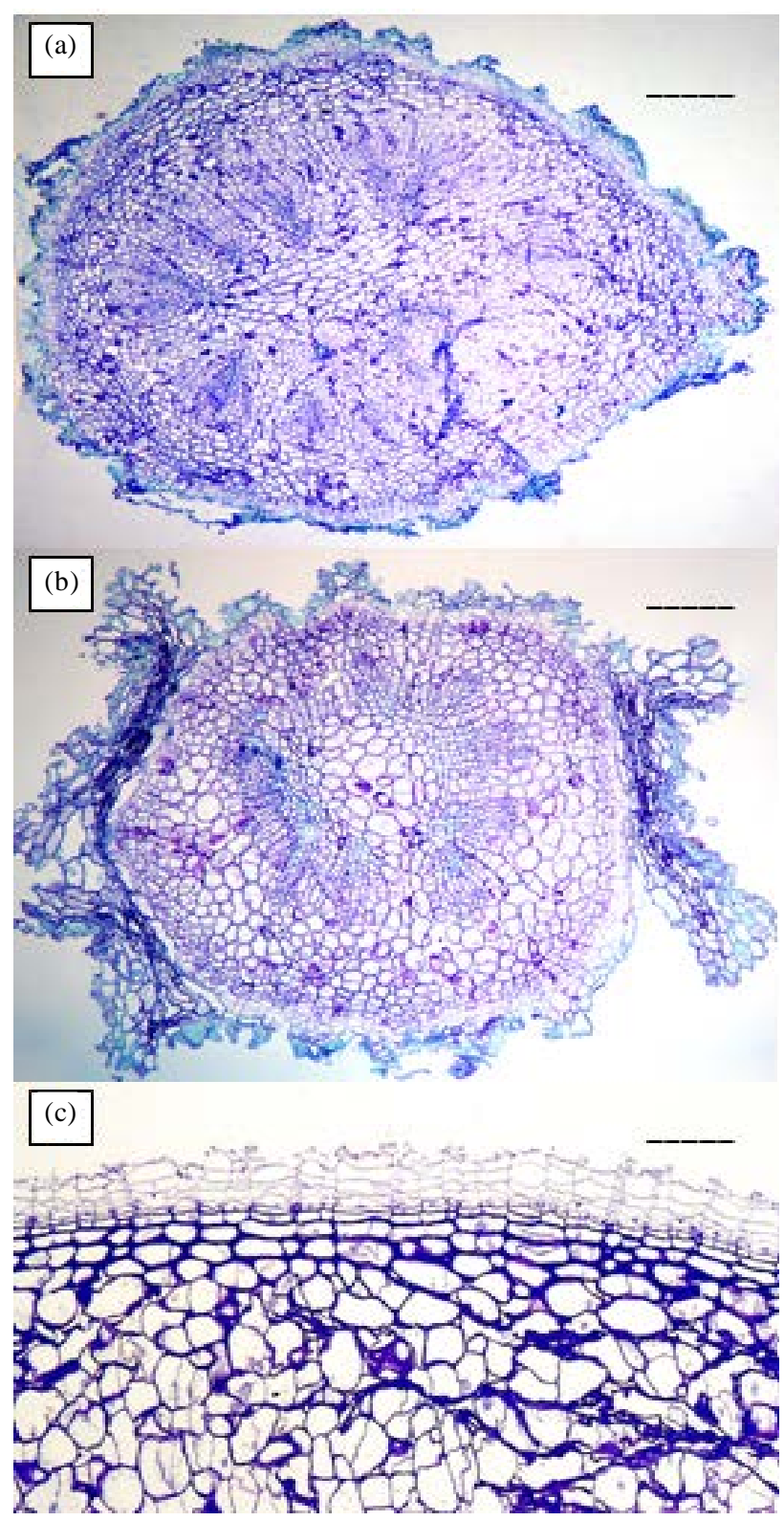

Figure 3. Light microscopic images of thin sections made through whole seedling roots with stripe symptoms. (a) The clusters of epidermal cells that form the ridges are stained blue and can be seen over the entire root surface; (b) a later stage of stripe root in which the epidermal cells are being sloughed off by the formation of an abscission zone; (c) control root showing intact epidermis and absence of fissures. Scale bar $=1 \mathrm{~mm}$.

concentration (wt [\%]), the levels of aluminum, calcium, iron and silicon were found to be higher and potassium lower in striped tissues (Table 1). As well, magnesium and phosphorus were slightly higher in striped tissues.

\subsection{Mineral Element Determination}

Analysis of striped root tissues and healthy tissues by Inductively Coupled Plasma Atomic Emission Spectrometry confirmed the results obtained by SEM-EDX. Levels of aluminum and iron were markedly higher in striped tissues, and magnesium and manganese levels were slightly higher (Table 2). In healthy tissues, levels of copper and zinc were increased. 

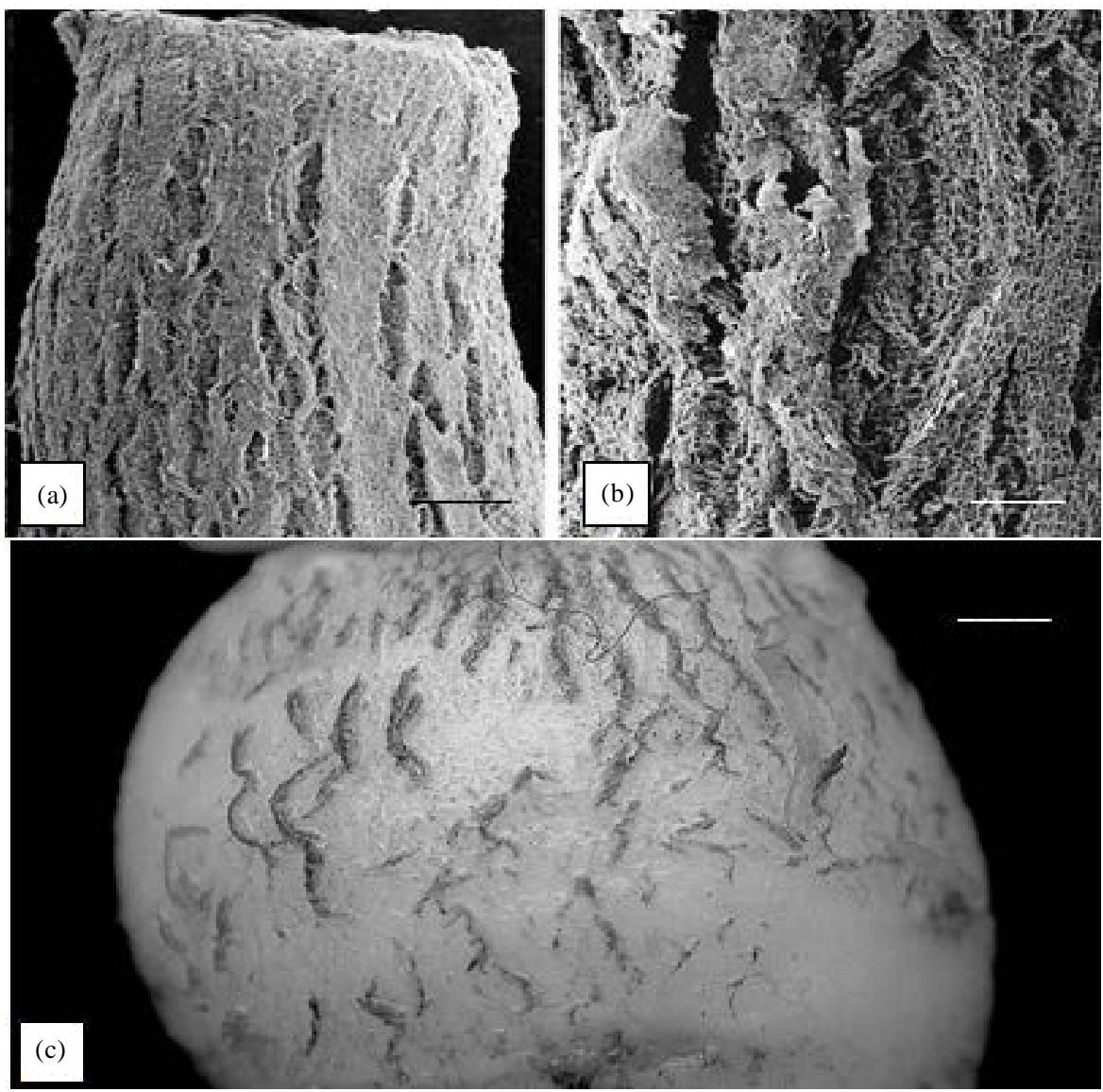

Figure 4. Scanning electron microscopic images of a seedling root with stripe symptoms. (a) Small fissures (cracks) can be seen in the epidermis which expose the underlying cortical cells; (b) close-up of a large fissure showing the formation of ridge tissues on both sides of the crack; (c) seedling root showing ridges of pigmented tissues on the root surface. Scale bar $=0.5 \mathrm{~cm}$.

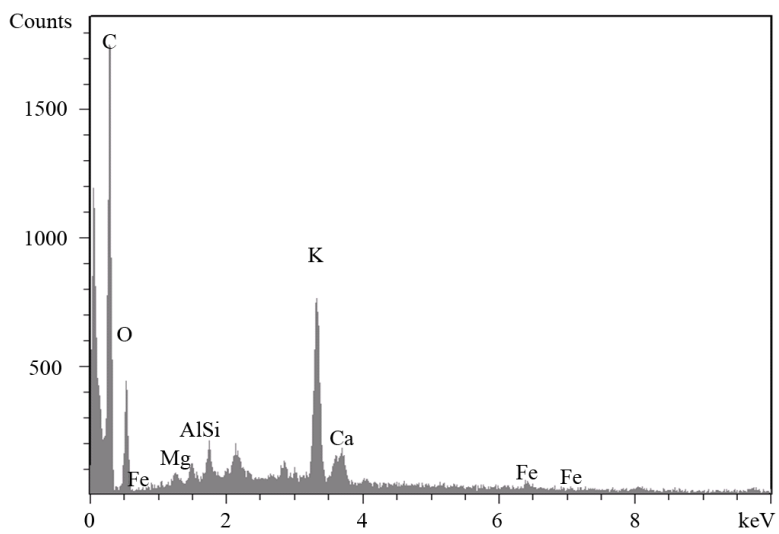

(a)

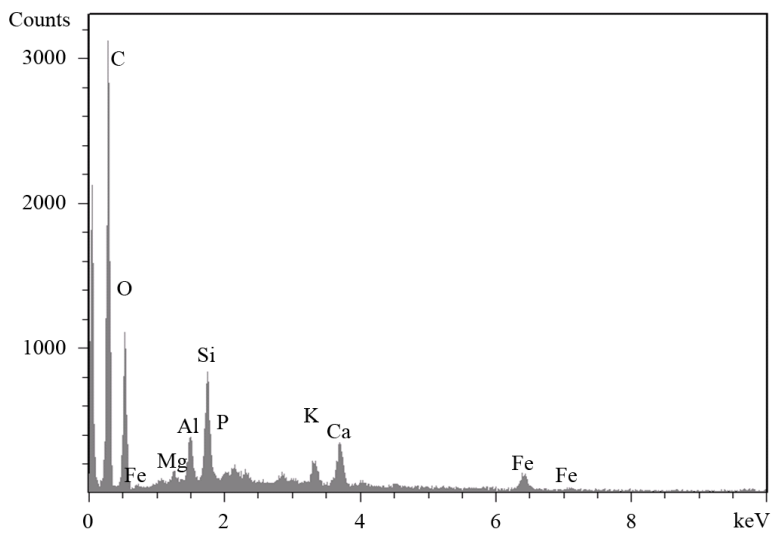

(b)

Figure 5. SEM-EDX spectrum analysis of healthy ginseng seedling roots (a) compared to striped roots (b).

\subsection{Phenolic Compounds and Enzyme Assays}

Total phenolic levels in extracts from striped root tissues were almost $80 \%$ higher compared to healthy tissues (69 $\mu \mathrm{g} / \mathrm{g}^{-1}$ gallic acid equivalents (GAE) compared to $38 \mu \mathrm{g} / \mathrm{g}^{-1}$, respectively). When examined by HPLC analysis, 
Table 1. Levels of specific mineral elements in healthy ginseng epidermal tissues compared with epidermal tissues showing stripe symptoms as determined by SEM-EDX.

\begin{tabular}{ccc}
\hline Element & Healthy Root (\%) & Stripe Root (\%) \\
\hline Aluminum & 0.0 & 1.13 \\
Calcium & 1.24 & 1.97 \\
Iron & 0.71 & 1.92 \\
Magnesium & 0.0 & 0.28 \\
Manganese & 0.0 & 0.11 \\
Phosphorus & 0.0 & 0.33 \\
Potassium & 7.12 & 0.75 \\
Silicon & 0.54 & 3.13 \\
Sulphur & 0.0 & 0.24 \\
\hline
\end{tabular}

Data are the average from two replicate samples and are expressed as concentration [wt. (\%)]. The SEM-EDX profiles are shown in Figure 5. Carbon and oxygen were estimated to be $55 \%$ and $35 \%$, respectively.

Table 2. Nutrient levels in healthy and stripe-affected ginseng root tissues as determined by ICP-AES.

\begin{tabular}{ccc}
\hline Element & Healthy Root & Stripe Root \\
\hline Macronutrients $(\mathrm{mg} / \mathrm{g})$ & & 2.6 \\
Calcium & 2.5 & 2.4 \\
Magnesium & 1.8 & 1.6 \\
Phosphorus & 1.4 & 1.8 \\
Potassium & 1.7 & 0.3 \\
Sodium & 0.3 & 0.8 \\
Sulphur & 0.6 & \\
Micronutrients (ug/g) & & 334 \\
Aluminum & 115 & 27.6 \\
Boron & 24.8 & 15.6 \\
Copper & 33.1 & 232 \\
Iron & 90.1 & 40.7 \\
Manganese & 24.7 & 0.7 \\
Molybdenum & 0.8 & 32.7 \\
Zinc & 41.5 & \\
\hline
\end{tabular}

Data are the average of two replicate samples. The analysis was conducted twice using tissues bulked from different roots. Representative data from one analysis are shown.

several phenolic compounds showed higher peaks at specific retention times between 10 and 25 min in extracts from striped root tissues compared to healthy roots (Figure 6). By using specific phenolic compounds as standards, some of these higher peaks on the chromatogram were identified as chlorogenic acid, quercetin, protocatechuic acid, O-coumaric acid, catechin and gallic acid (data not shown). The levels of the enzymes phenyalalanine ammonium lyase (PAL) and peroxidase (POD) were also found to be higher in extracts from striped tissues compared to healthy tissues (24.5 and 16.5 units of PAL and 7.2 and 4.6 units of POD, respectively. The data were averaged from 3 replicate samples). 


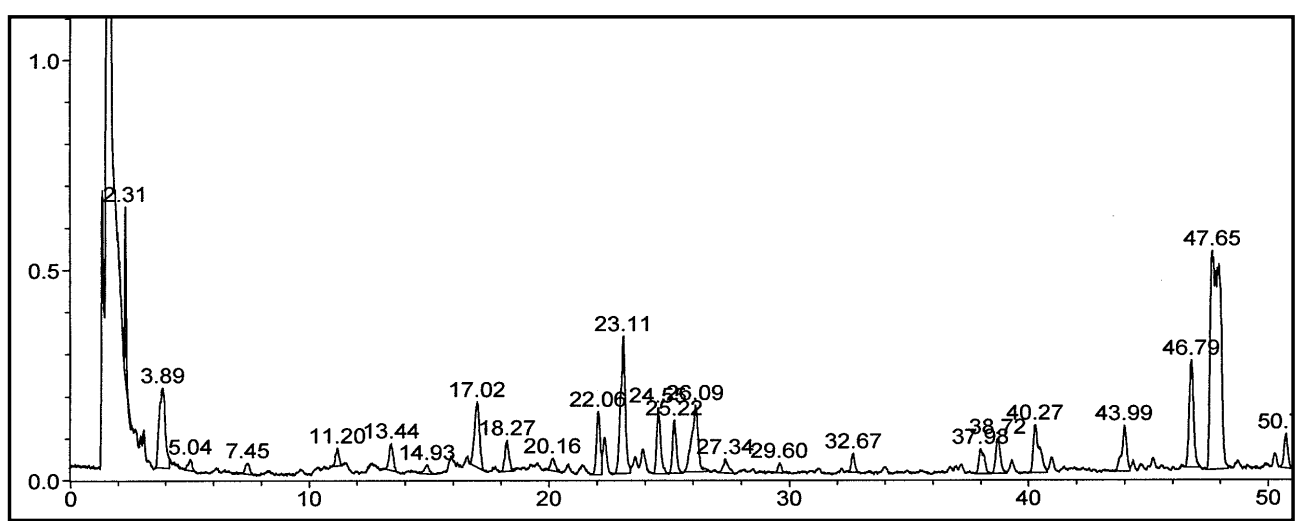

(a)

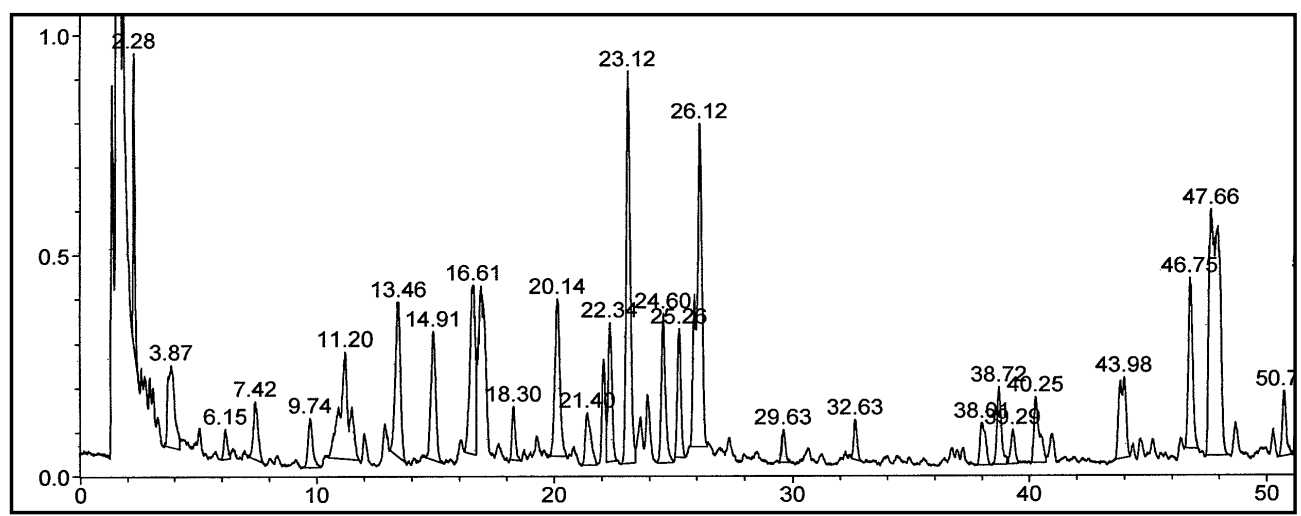

(b)

Figure 6. HPLC chromatograms of phenolic compounds extracted from healthy roots (a) compared to stripe roots (b).

\section{Discussion}

The results from this study show that the symptom of stripes on ginseng seedling roots is caused by a rupture (fissure) of the epidermal tissues to produce ridges of phenolic-containing cells that accumulate a number of positively-charged elements such as silicon, iron and aluminum. The fissures are likely a result of growth cracks, occurring when roots undergo a rapid increase in cell growth or expansion due to increased nutrient availability or water supply. Most of the symptoms were seen on roots later in the growing season (August-September) when seasonal growth was nearing completion. Warm and dry weather during this period is accompanied by frequent applications of irrigation water. Cracking of roots has been reported to occur in carrots under conditions of excessive nitrogen supply and moisture availability and occurred towards the end of the growing season [15]. A similar phenomenon has been reported to occur in potato tubers, where they are referred to as "growth cracks" [16] [17]. The frequency of growth cracks in potato increases when relatively poor growing conditions, such as prolonged moisture stress or high temperatures, are rapidly followed by relatively good growing conditions, such as excessive irrigation or rainfall, and it is also made worse if nitrogen fertilizer is applied in excess [16] [17]. Cracks in the cuticle of fruits such as cherries and tomatoes were also shown to be due to sudden increases in growth of the fruit or following increased turgor in the underlying pericarp cells due to rapid water uptake that placed a strain on the epidermis [18] [19]. The symptoms on ginseng roots also resembled the large cracks that develop naturally on the bark of certain coniferous tree species such as Douglas fir.

The reddening of the affected tissues was a marked symptom of striping and is a typical response of ginseng roots to mechanical injury or invasion by fungal pathogens [8] [10]. The secretion of phenolic compounds by damaged cells, followed by oxidation and coupled by sequestration of elements such as iron were reported to be involved in "rust spot" symptoms [5]-[7]. The browning reaction seen in wounded or damaged plant tissue, such as in apples and potatoes, is also the result of oxidation of phenolic compounds released from damaged cells by 
polyphenol oxidase enzymes to form brown-colored products [20]. Similarly, physical abrasion to the surface of peach and nectarine fruits caused brown and/or black spots to appear due to cell disruption in the epidermal and hypodermal cell layers [21]. Phenolic compound secretion by plant cells serves as a defense response to biotic and abiotic stresses [22]. Many phenolic compounds display antimicrobial activity and play an important role in the defense response of plants against diseases [23]. Polyphenols, especially tannins, are also known for their ability to chelate heavy metals, such as Fe, and play a role as potential antioxidants [24].

Phenolic compounds have been shown to be involved with metal chelation both in vitro and in vivo [25] [26]. While studying metallo-phenolic complex formation in peach and nectarine epidermal tissues, Cheng and Crisosto [26] demonstrated that elevated levels of the phenolic compounds caffeic acid, chlorogenic acid, and catechin chelated iron to form an iron-polyphenol complex, which led to tissue discoloration. We observed higher levels of chlorogenic acid, quercetin, catechin, and a number of other compounds, suggesting that these phenolics could be important in sequestering elements such as Fe, Si and Al. The observed increase in elemental concentration in ginseng striped tissues compared to healthy tissues in this study was likely due to metal chelation by these elevated phenolic compounds. The lower levels of potassium observed in striped tissues could be inversely related to the elevated concentrations of di and tribasic cations, which may have replaced $\mathrm{K}+$ ions by cation exchange. Most phenolic compounds have ortho-dihydroxyl groups which are involved in forming metal complexesand also have a low affinity for $\mathrm{K}+$ [27] [28].

One of the key enzymes involved in the metabolic pathway leading towards phenolic synthesis in plants is L-Phenylalanine ammonia-lyase (PAL) [22]. There is a large body of evidence illustrating a strong correlation between increases in PAL gene/protein expression/activity and increased levels of phenolic compounds in response to different stimuli [22]. In addition, peroxidase (POD) plays an important role in wound-healing and repair of damaged plant tissues [23]. The activities of both of these enzymes were higher in ginseng striped tissues compared to healthy tissues, suggesting they were involved in the higher phenolic production and tissue repair following the rupture of the epidermal cells. The sloughing off of the affected epidermal tissues and the formation of an abscission zone involve peroxidases that can catalyze the formation of lignin [29]. In many respects, the biochemical changes observed in the present study following the rupture of the epidermal cells is similar to the generalized defense responses in ginseng roots to pathogen infection [30]. However, root striping appears to be a physiological condition and does not resemble any of the previously described symptoms associated with ginseng pathogens [3] [8] [10].

\section{Acknowledgements}

We thank Chai-Na-Ta Ginseng Corp. for providing access to ginseng farms for sample collection, A. Wan for providing technical assistance, and the Natural Sciences and Engineering Research Council of Canada for funding this research through the Discovery Grants Program.

\section{References}

[1] Punja, Z.K. (2011) American Ginseng: Research Developments, Opportunities, and Challenges. Journal of Ginseng Research, 35, 368-374. http://dx.doi.org/10.5142/jgr.2011.35.3.368

[2] Proctor, J.T.A. and Bailey, W.G. (1987) Ginseng: Industry, Botany, and Culture. Horticultural Reviews, 9, $188-236$. http://dx.doi.org/10.1002/9781118060827.ch6

[3] Punja, Z.K. (1997) Fungal Pathogens of American Ginseng (Panax quinquefolius L.) in British Columbia, Canada. Canadian Journal of Plant Pathology, 19, 301-306. http://dx.doi.org/10.1080/07060669709500528

[4] Schluter, C. and Punja, Z.K. (2002) Genetic Diversity among Natural and Cultivated Field Populations and Seed Lots of American Ginseng (Panax quinquefolius L.) in Canada. International Journal of Plant Science, 163, 427-439. http://dx.doi.org/10.1086/339512

[5] Lee, T.S., Mok, S.K., Seon, S.K., Yoon, J.H., Baek, N.I. and Choe, J. (2004) Accumulation of Crude Lipids, Phenolic Compounds, and Iron in Rusty Ginseng Root Epidermis. Journal of Ginseng Research, 28, 157-164. http://dx.doi.org/10.5142/JGR.2004.28.3.157

[6] Campeau, C., Proctor, J.T.A., Murr, D.P. and Schooley, J. (2003) Characterization of North American Ginseng RustSpots and the Effects of Ethephon. Journal of Ginseng Research, 27, 188-194. http://dx.doi.org/10.5142/JGR.2003.27.4.188

[7] Yingping, W., Zhihong, L., Yanjun, S., Shiwei, G., Shuzhen, T. and Zhorong, L. (1997) Studies on the Genesis of Ginseng Rust Spots. Korean Journal of Ginseng Science, 21, 69-77. 
[8] Punja, Z.K., Wan, A., Goswami, R., Verma, N., Rahman, M., Barasubiye, T., Seifert, K. and Lévesque, C.A. (2007) Diversity of Fusarium Species Associated With Discolored Ginseng Roots in British Columbia. Canadian Journal Plant Pathology, 29, 340-353. http://dx.doi.org/10.1080/07060660709507480

[9] Reeleder, R.D., Roy, R. and Capell, B.B. (1999) Seed and Root Rots of Ginseng (Panax quinquefolius) Caused by Cylindrocarpon destructans and Fusarium spp. Journal of Ginseng Research, 26, 151-158.

[10] Punja, Z.K., Wan, A., Lieppi, L., Goswami, R.S. and Jayaraj, J. (2013) Growth, Pathogenicity, Infection Behaviour, and Genetic Diversity of Rhexocercosporidium Isolates Originating From Ginseng Fields in British Columbia. Canadian Journal of Plant Pathology, 35, 503-513. http://dx.doi.org/10.1080/07060661.2013.843315

[11] Gerrity, R.G. and Forbes, G.W. (2003) Microwave Processing in Diagnostic Electron Microscopy. Microscopy Today, 11, 38-41.

[12] Dahlquist, R.L. and Knoll, J.W. (1978) Inductively Coupled Plasma-Atomic Emission Spectrometry: Analysis of Biological Materials and Soils for Major, Trace, and Ultra-Trace Elements. Applied Spectroscopy, 32, 1-29. http://dx.doi.org/10.1366/000370278774331828

[13] Singleton, V.L., Orthofer, R. and Lamuela-Raventos, R.M. (1999) Analysis of Total Phenols and Other Oxidation Substrates and Antioxidants by Means of Folin-Ciocalteau Reagent. Methods in Enzymology, 299, 152-178. http://dx.doi.org/10.1016/S0076-6879(99)99017-1

[14] Bradford, M.M. (1976) A Rapid and Sensitive Method for the Quantitation of Microgram Quantities of Protein Utilizing the Principle of Protein-Dye Binding. Analytical Biochemistry, 72, 248-254. http://dx.doi.org/10.1016/0003-2697(76)90527-3

[15] Hartz, T.K., Johnstone, P.R. and Nunez, J.J. (2005) Production Environment and Nitrogen Fertility Affect Carrot Cracking. HortScience, 40, 611-615.

[16] Hiller, L.K., Koller, D.C. and Thornton, R.E. (1985) Physiological Disorders of Potatoes. In: Li, P.H., Ed., Potato Physiology, Academic Press, New York, 389-455.

[17] Jefferies, R.A. and MacKerron, D.K.L. (1987) Observations on the Incidence of Tuber Growth Cracking in Relation to Weather Patterns. Potato Research, 30, 613-623. http://dx.doi.org/10.1007/BF02367642

[18] Emmons, C.L. and Scott, J.W. (1996) Factors Affecting Cuticle Cracking in Tomato. Proceedings of the Florida State Horticultural Sciences, 109, 178-182.

[19] Peschel, S. and Knoche, M. (2005) Characterization of Microcracks in the Cuticle of Developing Sweet Cherry Fruit. Journal of the American Society for Horticultural Science, 130, 487-495.

[20] Ramirez, E.C., Whitaker, J.R. and Virador, V.M. (2002) Polyphenol Oxidase. In: Whitaker, J.R., Voragen, A.G.J. and Wong, D.W.S., Eds., Handbook of Food Enzymology, Marcel Dekker, New York, 509-523. http://dx.doi.org/10.1201/9780203910450.ch39

[21] Crisosto, G.W., Johnson, R.S. and Luza, J. (1993) Incidence of Physical Damage on Peach and Nectarine Skin Discoloration Development: Anatomical Studies. Journal of the American Society for Horticultural Science, 118, 796-800.

[22] Boudet, A.-M. (2007) Evolution and Current Status of Research in Phenolic Compounds. Phytochemistry, 68, 27222735. http://dx.doi.org/10.1016/j.phytochem.2007.06.012

[23] Nicholson, R.L. and Hammerschmidt, R. (1998) Phenolic Compounds and Their Role in Disease Resistance. Annual Review of Phytopathology, 30, 369-389. http://dx.doi.org/10.1146/annurev.py.30.090192.002101

[24] Rice-Evans, C.A., Miller, N.J. and Paganga, G. (1996) Structure-Antioxidant Activity Relationship of Flavonoids and Phenolic Acids. Free Radical Biology in Medicine, 20, 933-956. http://dx.doi.org/10.1016/0891-5849(95)02227-9

[25] Brune, M., Rossander, L. and Hallberg, L. (1989) Iron Absorption and Phenolic Compounds: Importance of Different Phenolic Structures. European Journal of Clinical Nutrition, 43, 547-558.

[26] Cheng, G.W. and Crisosto, C.H. (1997) Iron-Polyphenol Complex Formation and Skin Discoloration in Peaches and Nectarines. Journal of the American Society for Horticultural Science, 122, 95-99.

[27] Lavid, N., Schwartz, A., Yarden, O. and Tel-Or, E. (2000) The Involvement of Polyphenols and Peroxidase Activities in Heavy-Metal Accumulation by Epidermal Glands of the Waterlily (Nymphaeceae). Planta, 212, 323-331. http://dx.doi.org/10.1007/s004250000400

[28] Khokhar, S. and Richard, K.A.O. (2003) Iron Binding Characteristics of Phenolic Compounds: Some Tentative Structure-Activity Relations. Food Chemistry, 81, 133-140. http://dx.doi.org/10.1016/S0308-8146(02)00394-1

[29] Poovaiah, B.W. (1973) Peroxidase Activity in the Abscission Zone of Bean Leaves during Abscission. Plant Physiology, 52, 263-267. http://dx.doi.org/10.1104/pp.52.3.263

[30] Goswami, R. and Punja, Z.K. (2008) Molecular and Biochemical Characterization of Defense Responses in Ginseng (Panax quinquefolius) Roots Challenged with Fusarium equiseti. Physiological and Molecular Plant Pathology, 72 , 10-20. http://dx.doi.org/10.1016/j.pmpp.2008.04.006 